\title{
About the staff
}

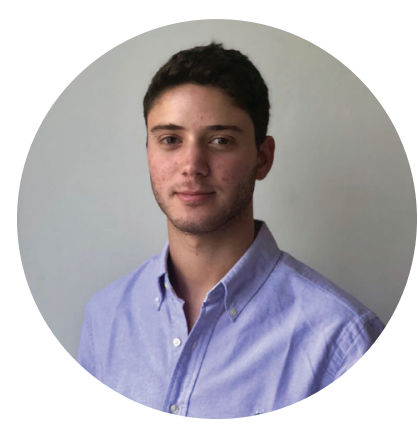

\section{Itai Palmon}

\section{Editor in Chief}

Itai is a junior from Palo Alto, CA studying Biophysics and Biochemistry. After graduating, he hopes to attend medical school. In addition to his work for UMURJ, Itai studies molecular dynamics in a structural chemistry lab. He is also the president of the Pre-Surgical club, and is a teaching assistant for introductory molecular biology. In his free time, he loves to spend time with friends and play the piano.

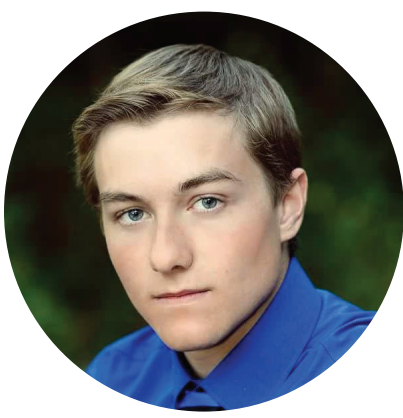

\section{Matt Ward}

Editor in Chief

Matt is a junior studying Biochemistry with a minor in German Studies. In addition to coleading UMURJ, Matthew spends a large amount of his time in the Lyssiotis Lab studying choline metabolism in pancreatic cancer. He plans to use his degree to enter the research community upon completing graduate school. Outside of his studies, Matthew enjoys fencing and reading.

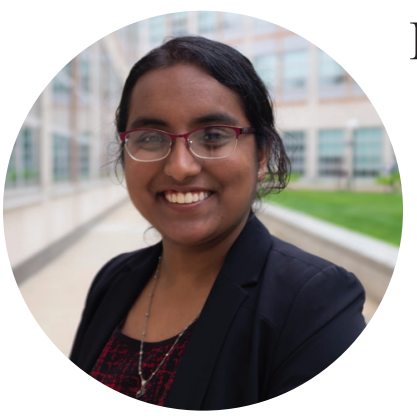

\section{Ruchica Chandnani}

Editor-in-Chief Emeritus

Ruchica is currently a senior in the College of LSA majoring in Biopsychology, Cognition, and Neuroscience and minoring in Asian Languages. Along with being the first Editor-in-Chief Emeritus for UMURJ, she is also a Diversity Peer Educator for the Northwood 3 community and the President of the Mortar Board Senior Honors Society. Right now, she's planning to become a DO doctor in Arkansas after she finishes up her thesis and graduates this semester.

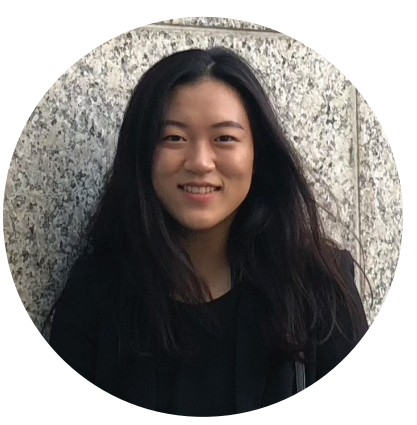

\section{Anna Kang}

Associate Editor

Anna is a junior in the College of LSA majoring in Chemistry. She is an undergraduate researcher in the Cernak Group studying medicinal chemistry and hopes to attend medical school in the fall of 2020 in pursuit of radiology. 


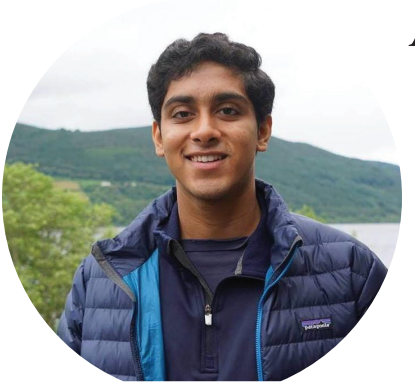

\section{Abhiram Bukkapatnam}

\section{Associate Editor}

Abhi is a junior studying Economics from Tampa, Florida. In addition to working as an editor for UMURJ, he participates in research at Michigan and was a member of the Michigan Student Orchestra. In his free time, he enjoys reading, watching movies, and spending time with his friends.

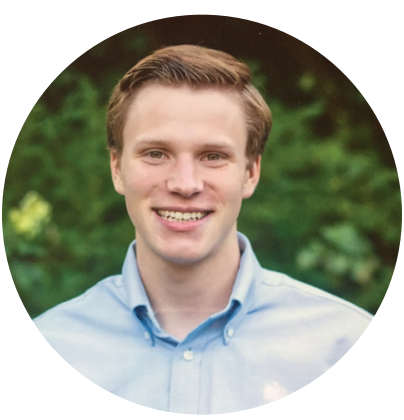

\section{Grant Bennett}

Associate Editor

Grant is a sophomore from Ann Arbor studying Environmental Engineering. In the future, he's interested in studying urban planning and the built environment after graduating and hopes to work in sustainable and equitable city design. Outside of his role in the journal, Grant is active in the Climate Action Movement. In his free time, he has recently taken up racquetball and loves to go backpacking whenever he gets the chance.

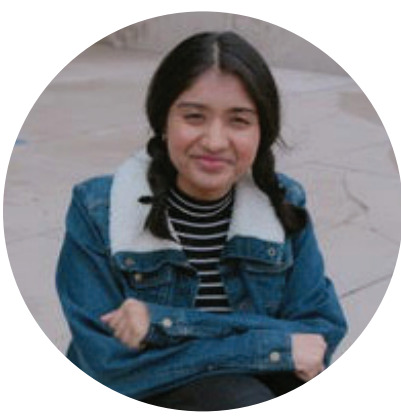

\section{Sai Pamidighantam}

Public Relations Chair

Sai is from Columbus, Indiana but is so glad she was able to get away from all the corn and come to Michigan! With degrees in Biopsychology, Cognition, and Neuroscience, and Applied Statistics, Sai plans on pursuing an $\mathrm{MD} / \mathrm{PhD}$ and taking on a career in medical practice and research. On campus, she is an elected representative of the LSA Student Government, a volunteer of SAPAC's CORE division, and a HELP volunteer for UMHS. In her free time, she enjoys spending time with her friends, playing her electric bass, or painting.

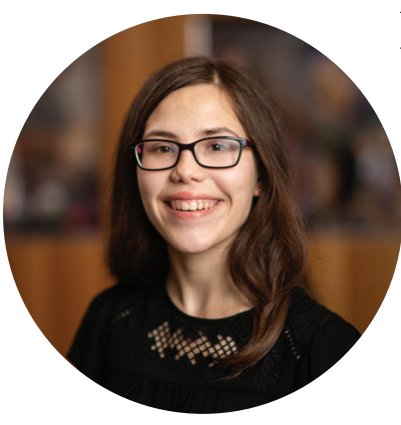

\section{Estrella Salgado}

\section{Copy Editor}

Estrella is currently a sophomore majoring in History with a focus on the United States and minoring in Museum Studies. Through the Honors Program, she mentors students as an Academic Peer Advisor and contributes to rousing debates at Honors Reads. You can spot her leading a campus tour for prospective students, admiring art at the UMMA, or stopping in a campus café for a pumpkin chocolate chip muffin. Eventually, she would love to earn a joint $\mathrm{PhD}$ in History and Women's Studies. 


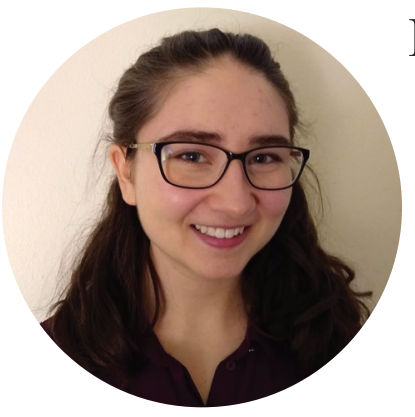

\section{Michaela Yamine}

Copy Editor

Michaela Yamine is sophomore from Novi, Michigan studying Molecular, Cellular, and Developmental Biology and Biological Anthropology. Her interests include population genetics, public health, and gene modification. After graduation, she plans to pursue a $\mathrm{PhD}$ related to the interplay between environment and biology. In her free time, she enjoys listening to podcasts and spending time with friends.

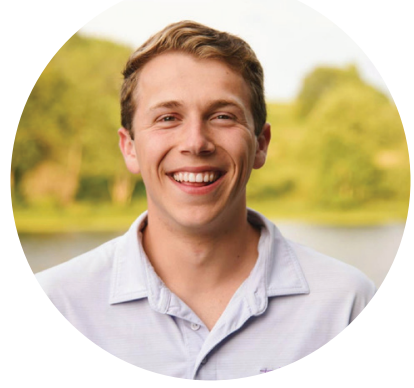

\section{Hunter Cohn}

\section{Copy Editor}

Hunter is a junior from Columbus, Ohio majoring in Organizational Studies. In his free time, he enjoys reading books, watching movies, and traveling. In the future, Hunter would like to bridge his experiences in the social sciences with his interests in the natural sciences by pursuing an MD/MBA. At some point, Hunter hopes to live abroad in both South America and the Middle East.

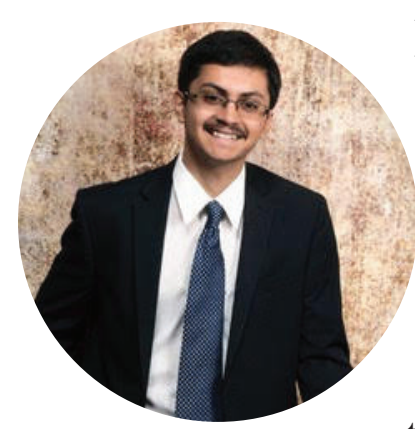

\section{Ranganath Kathawate}

Copy Editor

Ranganath is a sophomore in LSA studying Biology. From Lake Orion, Michigan, Ranganath plans to go on into a career in medicine. In addition to his involvement with UMURJ, Ranganath is a research assistant in the Department of Surgery working on projects relevant to trauma and resuscitation, with particular relevance to battlefield injuries. He is also a cofounder and director of the University of Michigan Science Olympiad, which is an organization that hosts an annual science competition for over 900 high school students. In his spare time, Ranganath loves to watch movies, spend time with friends, and devour ice cream cones.

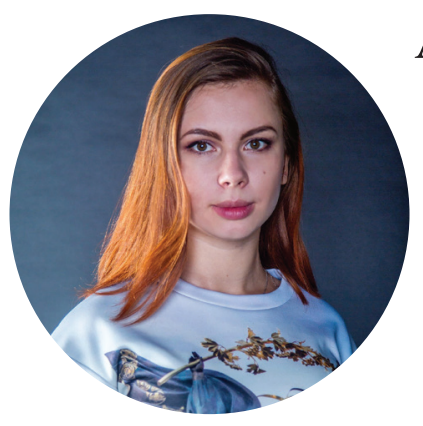

\section{Alice Sorel}

\section{Copy Editor}

Alice is a junior majoring in Cognitive Science, Philosophy and Cognition track. She works as a research assistant in a neuroscience lab, trying to understand how genetics affects brain development. Reading, traveling, spending time with the animals and visiting bookstores are among her other favorite things.

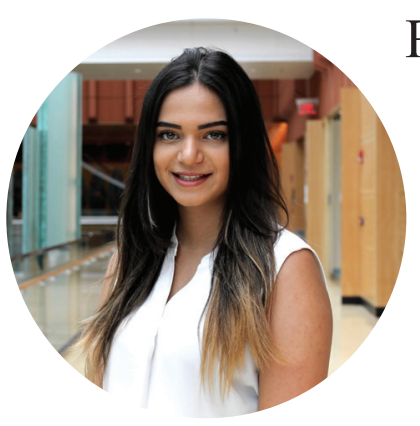

\section{Ria Paradkar}

\section{Copy Editor}

Ria is a freshman studying Business and Biomolecular Science from Tokyo, Japan. She plans to go into the field of healthcare consulting and eventually plans on receiving her MBA. In addition to serving as a life sciences editor for UMURJ, Ria is a part of MECC Consulting Group and works as a research assistant in the MCDB department. 


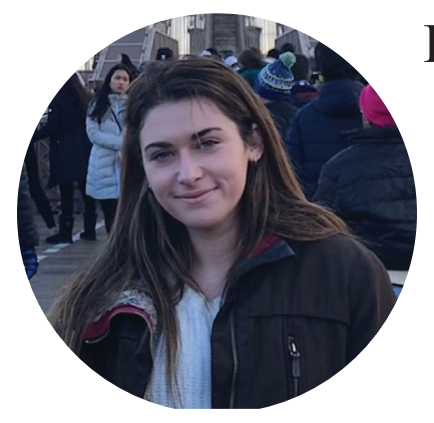

\section{Dani Maydan \\ Copy Editor}

Dani is a sophomore from Palo Alto, CA. She is studying Psychology and Cellular and Molecular Biology, and hopes to pursue an MD-PhD. In addition to being a life sciences editor for the Undergraduate Research Journal, Dani works as a research assistant in a laboratory studying pancreatic cancer metabolism. In her free time, she enjoys spending time with friends and playing soccer.

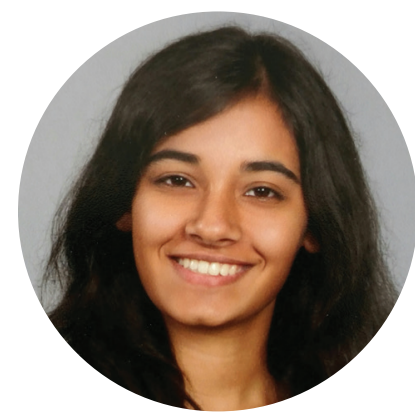

\section{Natasha Badami}

\section{Copy Editor}

Natasha is a sophomore studying Computer Science through the College of Engineering. She is interested in exploring theoretical computer science and potentially pursuing a $\mathrm{PhD}$ therein. Currently, she is a research assistant for a project that aims to create a machine learning system to classify the behaviors of a specific organism. In her free time, she enjoys hiking, drawing, making costumes, and learning languages.

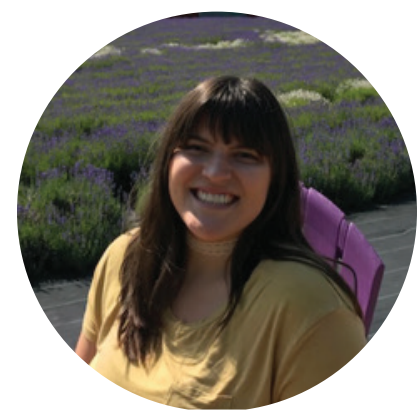

\section{Kaitlyn Hines}

\section{Copy Editor}

Kaitlyn is a current sophomore in the College of Literature, Science, and the Arts from East Jordan, MI. She is double-majoring with Environment and Biology, Health, and Society (BHS). Kaitlyn would love to continue on with Public Health and obtain an MPH. Outside of the UMURJ, she is a peer mentor for the Sustainable Living Experience and the Fundraising Co-Head for the student led nonprofit Global Brigades.

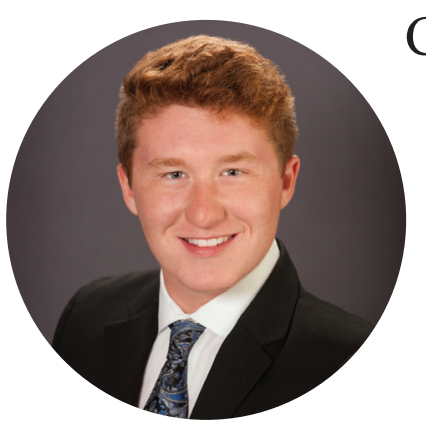

\section{Cameron Craig}

Copy Editor

Cameron Craig is a junior studying Biophysics with a Minor in Business. His goal is to study medicine and become a surgeon. 